\title{
A rare FANCA gene variation as a breast cancer susceptibility allele in an Iranian population
}

\author{
SAKINEH ABBASI $^{1}$ and MINA RASOULI ${ }^{2}$ \\ ${ }^{1}$ Department of Laboratory Medicine, School of Allied Medical Sciences, Tehran University of Medical Sciences, \\ Tehran 14177, Iran; ${ }^{2}$ Laboratory of Vaccines and Immunotherapeutics, Institute of Bioscience, \\ University Putra Malaysia, Serdang, Selangor 43400, Malaysia
}

Received July 1, 2016; Accepted February 13, 2017

DOI: $10.3892 / \mathrm{mmr} .2017 .6489$

\begin{abstract}
Fanconi Anemia (FA) is an autosomal recessive syndrome characterized by congenital abnormalities, progressive bone marrow failure and Fanconi anemia complementation group A $(F A N C A)$ is also a potential breast and ovarian cancer susceptibility gene. A novel allele with tandem duplication of 13 base pair sequence in promoter region was identified. To investigate whether the 13 base pair sequence of tandem duplication in promoter region of the FANCA gene is of high penetrance in patients with breast cancer and to determine if the presence of the duplicated allele was associated with an altered risk of breast cancer, the present study screened DNA in blood samples from 304 breast cancer patients and 295 normal individuals as controls. The duplication allele had a frequency of 35.4 and $21.2 \%$ in patients with breast cancer and normal controls, respectively. There was a significant increase in the frequency of the duplication allele in patients with familial breast cancer compared with controls $(45.1 \%$, $\mathrm{P}=0.001)$. Furthermore, the estimated risk of breast cancer in individuals with a homozygote [odds ratio (OR), 4.093; $95 \%$ confidence intervals (CI), 1.957-8.561] or heterozygote duplicated genotype (OR, 3.315; 95\% CI, 1.996-5.506) was higher compared with the corresponding normal homozygote genotype. In conclusion, the present study indicated that the higher the frequency of the duplicated allele, the higher the risk of breast cancer. To the best of our knowledge, the present study is the first to report FANCA gene duplication in patients with breast cancer.
\end{abstract}

Correspondence to: Dr Sakineh Abbasi, Department of Laboratory Medicine, School of Allied Medical Sciences, Tehran University of Medical Sciences, 17 Farredanesh Alley, Ghoods Street, Enghelab Avenue, Tehran 14177, Iran

E-mail: sakineh4612004@yahoo.com

Key words: Fanconi anemia, breast cancer, duplication, polymerase chain reaction

\section{Introduction}

Breast cancer is the most common type of invasive cancer in women and accounts for $16 \%$ of all female cancers, with the second highest mortality rate among women worldwide (1), while in USA and Iran it comprises 26 and $23 \%$ of all female cancers (2-4), respectively. In addition, breast cancer is an important public health issue; with $\sim 8,000$ women being diagnosed annually in Iran, of which $97.2 \%$ are women. However, due to the relatively early diagnosis, it is the fifth most common cause of cancer death in Iran (3). The two major susceptibility genes, BRCA1 and BRCA2, account for a maximum of $20 \%$ of familial breast cancer cases worldwide. The remaining cases may be explained by mutations in other cancer susceptibility genes together with environmental factors (5).

The Fanconi anemia complementation group A (FANCA) gene is located at $16 \mathrm{q} 24.3$, and is primarily recognized as a gene involved in Fanconi anemia (FA), which is a rare autosomal recessive disorder with a prevalence of $\sim 1-5$ per million in the western world (6). FA genes are assigned into the following 8 distinct complementation FA groups: $F A N C A, F A N C B$, FANCC, FANCD1, FANCD2, FANCE, FANCF and FANCG. $F A N C A$ is the most common FA subtype in the majority of populations and is defective in $>65 \%$ of FA cases; FANCC, FANCG and FANCD2 each account for $~ 5-15 \%$ of cases, with the remaining subtypes being rare (6-8). Furthermore, $F A N C A$ is a potential tumor suppressor gene due to its role in the repair of DNA damage, and it remains an attractive candidate as either a cancer predisposition gene or a target of genetic sporadic cancer (9). The proteins encoded by FA genes are closely associated to each other in molecular pathways involved in DNA repair, and interact directly to form a multi-subunit nuclear complex (10) that is required to respond to DNA damage $(11,12)$. Notably, the $16 \mathrm{q} 24.3$ genomic region, where FANCA resides, is a common target for loss-of-heterozygosity in breast tumors (13), and in addition, an intronic FANCA single nucleotide polymorphism has been previously associated with an $8 \%$ increase in breast cancer risk (14). Only 1 potential FANCA missense mutation has been identified in UK families with breast cancer (15), and 4 large FANCA deletions have been previously reported in sporadic acute myeloid leukemia (16). As polymorphisms in promoters alter the transcription or regulation of a gene, it was hypothesized that 
the FANCA gene duplication in the promoter region may alter the risk of developing breast cancer in an Iranian population, similar to previous reports in other populations (17), and may be associated with an altered risk of developing breast cancer. The present study therefore performed a case control study to determine whether duplication allele may be responsible for an increase in the risk of breast cancer among a population of Iranian women.

\section{Materials and methods}

Subjects. A total of 304 breast cancer cases were systematically ascertained through Imam Khomeini Hospital Complex (Tehran University of Medical Sciences, Tehran, Iran). Of these cases, $50 \%$ (152) were selected on the basis of a family history of breast cancer (defined as $\geq 2$ cases of breast cancer in a first- or second-degree female relative). Blood was taken from all recruits who consented to molecular analysis for breast cancer predisposition genes at the Central Laboratory of Imam Khomeini Hospital Complex hospital. The age range of the all breast cancer participants was 28-74 with a mean age of $49.41 \pm 10.44$ years (familial and non-familial breast cancer). The controls were selected from the same population from which the cases arose and consisted of 295 healthy female volunteers who were attending the Cancer Institute of Imam Khomeini Hospital Complex for a checkup. The age range of the controls was 28-74 with a mean age of $49.28 \pm 10.48$ years. None of the control individuals had any history of breast cancer or any other neoplastic diseases, and had no family history of breast cancer diagnosed at the same clinics. Women with hysterectomy and artificial menopause, or who had been exposed to any kind of radiation, including $\mathrm{X}$-rays, or chemotherapy in their life time were excluded from the study. Control and cancer groups were drawn from the same geographical area. Demographical and epidemiological risk factor data was collected from a short, structured questionnaire, which included information on age at menarche, age at menopause, marriage status, race, age at breast cancer onset, number of pregnancies and children, age at first child birth and average lactation term. An ongoing protocol to collect and store blood samples for future genomic tests was approved by the institutional review board and appropriate ethics committee. Peripheral blood was collected and genotyping analysis was performed for selected regions in the FANCA gene.

Ethical approval and consent to participate. The study was approved by the Research Ethics Committee for Tehran University of Medical Sciences (IR.TUMS.REC.1395.2500). Informed consent for testing and publication was obtained from all participants prior to participation in the present study (or their parents/legal guardians).

Molecular genetic analysis. DNA for genotyping was prepared from the peripheral blood sample of patients and controls. The DNA promoter region containing the duplication (164 bp) was amplified using primers designed by Primer3 (version 0.4.0) software and positive control primers were used to amplify estrogen receptor 1 gene exon 4 (329 bp), as published elsewhere (18). Primer sequences are presented in Table I.
Phenol-chloroform DNA extraction. DNA was isolated using AccuPrep $^{\circledR}$ (high pure phenol-chloroform) Genomic DNA extraction kit (Bioneer Corporation; Takapouzist Co., Tehran, Iran). Lysis buffer $(200 \mu \mathrm{l})$ was added to $200 \mu \mathrm{l}$ whole blood and incubated at $60^{\circ} \mathrm{C}$ for $10 \mathrm{~min}, 500 \mu \mathrm{l}$ phenol was then added and centrifuged at $12,000 \times \mathrm{g}$ at $4^{\circ} \mathrm{C}$ for $5 \mathrm{~min}$. Chloroform $(500 \mu \mathrm{l})$ was added to the upper phase and centrifuged for $5 \mathrm{~min}$ at $12,000 \times \mathrm{g}$ at $4^{\circ} \mathrm{C}$. Sodium Acetate (1:10) plus cold $100 \%$ ethanol (2:1) was added to the upper phase, frozen for $20 \mathrm{~min}$ at $-20^{\circ} \mathrm{C}$ and centrifuged for $10 \mathrm{~min}$ at $12,000 \times \mathrm{g}$ and $4^{\circ} \mathrm{C}$. To precipitate DNA, $70 \%$ ethanol was added and centrifugation was performed for $15 \mathrm{~min}$ at $12,000 \mathrm{x} g$ and $4^{\circ} \mathrm{C}$. The DNA was measured using a spectrophotometer; the amount of DNA was calculated in $\mu \mathrm{g} / \mathrm{ml}(85 \mu \mathrm{g} / \mathrm{ml})$ by absorbance at $260 \mathrm{~nm}$ and the purity was tested by determining the $260 / 280 \mathrm{~nm}$ ratio (a ratio of 1.7 was detected).

Polymerase chain reaction (PCR) conditions. The following was added to each $50 \mu \mathrm{l}$ PCR reaction tube: $43.5 \mu 1$ master mix (5X HOT FIREPol ${ }^{\circledR}$ Blend; TAG Copenhagen A/S, Frederiksberg, Denmark); $2 \mu 1(200 \mathrm{nM})$ primers synthesized by TAG Copenhagen A/S; $2 \mu 1$ (50 ng) DNA template (extracted genomic DNA); and $2.52 \mu 1$ Taq DNA polymerase (0.5 U Super Taq enzymes; Cambridge Bioscience, Ltd., Cambridge, UK) and PCR was performed in an Eppendorf thermo-cycler following the protocol in Table II. The first set of PCR primers amplified a 151-base pair product for allele 0 (normal) and a 164 base pair product for allele 1 (duplication). The DNA ladder (Biotium) was also purchased from Cambridge Bioscience, Ltd. The products were separated by electrophoresis on $3 \%$ agarose gel and stained by $1 \%$ ethidium bromide (Cambridge Bioscience, Ltd.). PCR products from the three genotypes were sequenced on the 96-capillary ABI 3730xl (Applied Biosystems; Thermo Fisher Scientific, Inc., Waltham, MA, USA) by the Sanger sequencing technique.

Statistical analysis. The Hardy-Weinberg equilibrium was assessed by the standard methods (19). The data were considered using normal (00; women without a copy of the duplication allele), heterozygotes (01; women with 1 copy of the duplication allele) and homozygotes (11; women with 2 duplication alleles). Data was analyzed using SPSS, version 17.0 (SPSS, Inc., Chicago, IL, USA). Stratification with respect to demographics and risk factors was performed and post-stratification Pearson's $\chi^{2}$ analysis was used to calculate the significance and odds ratio (OR) with a $95 \%$ confidence interval. All tests were two-sided and $\mathrm{P}<0.05$ was considered to indicate a statistically significant difference.

\section{Results}

Identification of the FANCA promoter duplication. Variation in the FANCA gene promoter region (NCBI reference sequence, NM_000135.2) was screened using PCR analysis. Variant bands were purified and sequenced directly with forward and reverse primers. The comparison of band sequences and the sequence of the FANCA promoter demonstrated that a 13-base pair sequence (5'-GGCCACGACGCAA-3') located from -98 to -110 bases upstream of the transcription start point, which was present either as a single or double copy, causes variation 
Table I. Polymerase chain reaction primers.

\begin{tabular}{ll}
\hline Primer & \multicolumn{1}{c}{ Sequence $5 ' \rightarrow 3^{\prime}$} \\
\hline Duplicated region FANCA primers & F: CCAAACGCAAAAACTACCTCACCG \\
& R: CGCTGCCTTCCTATTGGCTGC \\
ESRl exon 4 primers (positive control) & F: ACCTGTGTTTTCAGGGATACGA \\
& R: GCTGCGCTTCGCATTCTTAC \\
\end{tabular}

FANCA, Fanconi anemia complementation group A; ESR1, estrogen receptor 1 gene exon 4; F, forward; R, reverse.

Table II. Polymerase chain reaction cycling conditions.

\begin{tabular}{llccc}
\hline $\begin{array}{l}\text { Step } \\
\text { number }\end{array}$ & Reaction & $\begin{array}{c}\text { Temperature } \\
\left({ }^{\circ} \mathrm{C}\right)\end{array}$ & $\begin{array}{c}\text { Duration } \\
(\mathrm{min})\end{array}$ & $\begin{array}{c}\text { Number } \\
\text { of cycles }\end{array}$ \\
\hline 1 & $\begin{array}{l}\text { Primary } \\
\text { denaturation }\end{array}$ & 94 & 4 & 1 \\
2 & Denaturation & 94 & 1 & 35 \\
3 & Annealing & 67 & 1 & 35 \\
4 & Extension & 72 & 1 & 35 \\
5 & Final & 72 & 5 & 2 \\
& extension & & & \\
\hline
\end{tabular}

in patterns observed on the agarose gel. In the present study, allele 0 is defined as having has a single copy of the sequence (5'-GGCCACGACGCAA-3'), whilst allele 1 has 2 tandem copies of this sequence. Notably, the sequence directly adjacent to (in the downstream direction) the 13-base pair sequence shares homology with the duplicate sequence.

Case-control study of FANCA variations. A single set of primers was used to amplify both alleles by PCR in the promoter region (Fig. 1). The frequency of the polymorphism was determined in patients with breast cancer and controls to assess if the presence of either allele was associated with a predisposition to breast cancer. Table III presents the genotypic frequency distribution in patients with breast cancer and controls. The distribution of the genotypes within overall breast cancer and familial breast cancer groups deviated significantly from those expected under Hardy-Weinberg equilibrium with a P-value of 0.001 . In patients with familial breast cancer, the estimated risk was 1.3 fold higher for individuals who were 01 heterozygote duplication (OR, 1.27; 95\% CI, $0.825-1.955)$ or 1.5 fold higher for those who were 11 homozygote duplication (OR, 1.511; 95\% CI, 0.73-3.131) compared with 00 homozygotes. Therefore, the results indicated that a higher frequency of allele 1 may be associated with an increased risk of developing familial breast cancer. However, the genotypic frequency did not show significant $(\mathrm{P}=0.365)$ elevation among the-non family history group. Furthermore, the frequency of the duplication allele (allele 1) in all breast cancer patients and familial breast cancer patients only was significantly higher compared with controls $(\mathrm{P}=0.001)$, with exception of non-familiar breast cancer patients $(\mathrm{P}=0.131$;

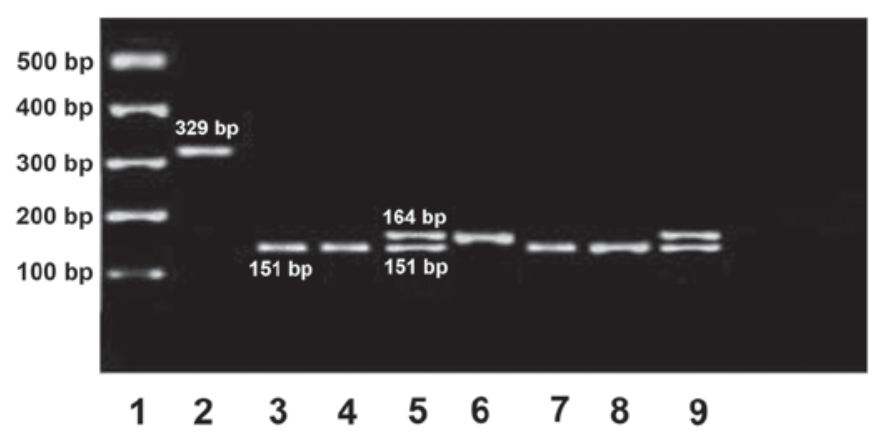

Figure 1. Genotyping the Fanconi anemia complementation group A promoter polymorphism by polymerase chain reaction. Allele 0 amplifies as a band of $151 \mathrm{bp}$ and allele 1 as a band of $164 \mathrm{bp}$. All 3 genotypes are readily distinguishable on a $3 \%$ agarose gel run at $100 \mathrm{~V}$ for $1 \mathrm{~h}$. Lane 1 , ladder; lane 2, estrogen receptor 1 exon 4 gene, positive control; lanes 3,4,7 and 8,00 homozygote; lane 5,01 heterozygote; and lane 6, 11 homozygote. bp, base pairs.

Table IV). Promoter duplication genotypes were compared with selected clinical breast cancer features, including age at menarche, age at breast cancer onset, age at menopause and lymph node metastasis in patients with breast cancer. The only significant association was for age at menarche, as indicated by the ORs presented in Table V. Genotype frequencies exhibited significantly different distributions in age at menarche $(<12$ years old vs. $\geq 12 ; \mathrm{P}=0.001)$. The estimated risk was higher for individuals who were 11 homozygotes for the duplication (OR 0.148, 95\% CI: 0.069-0.316) compared with the corresponding 01 heterozygotes (OR, 0.775; 95\% CI, 0.428-1.405). Furthermore, the estimated risk of developing breast cancer (familiar breast cancer vs. non-familiar breast cancer) was 4-fold higher for those who were 11 homozygotes (OR 4.093, 95\%; CI, 1.957-8.561) or 3-fold higher for those who were 01 heterozygotes (OR, 3.315; 95\% CI, 1.996-5.506) compared with the corresponding 00 homozygotes. The results suggest that the higher the frequency of allele 1, the greater the risk of developing breast cancer.

\section{Discussion}

To the best of our knowledge, the present study was the first to evaluate the association between variations in the FANCA gene, in 304 breast cancer cases, and breast cancer risk in Iranian women. As this duplication was relatively common in healthy individuals, it may be regarded as a polymorphism. It is already established that alterations in the FANC group 
Table III. The distribution of Fanconi anemia complementation group A gene promoter polymorphism genotypes and estimated risk in breast cancer cases and controls.

\begin{tabular}{|c|c|c|c|c|}
\hline \multirow[b]{2}{*}{ Group } & \multicolumn{3}{|c|}{ Study group } & \multirow[b]{2}{*}{ P-value } \\
\hline & 00 & 01 & 11 & \\
\hline Control (\%) & $190(64.4)$ & $85(28.8)$ & $20(6.8)$ & \\
\hline All breast cancer cases & & & & 0.001 \\
\hline Number $(\%)$ & $131(43.1)$ & $131(43.1)$ & $42(13.8)$ & \\
\hline OR $(95 \% \mathrm{CI})$ & 1.0 & $2.235(1.57-3.17)$ & $3.046(1.71-5.424)$ & \\
\hline Familial breast cancer cases & & & & 0.001 \\
\hline Number $(\%)$ & $43(28.3)$ & $81(53.3)$ & $28(18.4)$ & \\
\hline OR $(95 \% \mathrm{CI})$ & 1.0 & $1.27(0.825-1.955)$ & $1.511(0.73-3.131)$ & \\
\hline Non-familial breast cancer cases & & & & 0.365 \\
\hline Number $(\%)$ & $88(57.9)$ & $50(32.9)$ & $14(9.2)$ & \\
\hline OR $(95 \% \mathrm{CI})$ & 1.0 & $4.211(2.686-6.601)$ & $6.186(3.189-11.998)$ & \\
\hline
\end{tabular}

OR and $\mathrm{CI}$ for 01 and 11 groups are presented relative to that of 00.00 , normal genotype; 01, duplication heterozygote; 11, duplication homozygote; OR, odds ratio; CI, confidence interval.

Table IV. The distribution of Fanconi anemia complementation group A promoter polymorphism allelic frequencies in familial and non-familial breast cases compared with controls.

\begin{tabular}{lcccc}
\hline $\begin{array}{l}\text { Study } \\
\text { group }\end{array}$ & $\begin{array}{c}\text { Allele } 0 \\
(\%)\end{array}$ & $\begin{array}{c}\text { Allele } 1 \\
(\%)\end{array}$ & P-value & $\chi^{2}$ \\
\hline $\begin{array}{l}\text { All breast } \\
\text { cancer cases }\end{array}$ & $393(46.6)$ & $215(53.4)$ & 0.001 & 29.6 \\
$\begin{array}{l}\text { Control } \\
\text { Familial breast } \\
\text { cancer }\end{array}$ & $465(78.8)$ & $125(21.2)$ & & \\
$\begin{array}{l}\text { Control } \\
\text { Non-familial } \\
\text { breast cancer }\end{array}$ & $226(74.9)$ & $137(45.1)$ & 0.001 & 55.21 \\
Control & $465(78.8)$ & $125(25.7)$ & 0.131 & 2.286 \\
\hline
\end{tabular}

P-values indicate comparisons between the number of individuals with allele 0 and allele 1.0 , normal single copy allele; 1 , duplication allele.

of genes are associated with several types of cancer (20-23). Following the identification of BRCA2 as a member of the FANC family ( $F A N C D 1)$, researchers hypothesize that variations in other FANC genes, such as FANCA, may increase breast cancer susceptibility (24). For example, the absence of $F A N C F$ by aberrant promoter methylation $(25,26)$ and $B A C H 1 / F A N C J$ mutations (27) have been previously identified in breast cancer cases. Furthermore, deletions (28) and duplications (17) in the FANCA gene are pathogenic and have been previously detected in patients with breast cancer.

As even single base changes in gene sequences may change gene expression regulation and lead to tumorigenesis, particularly if this affects a transcription factor binding site $(17,29,30)$, the 13-base pair duplication alleles in the promoter region identified in the present study are important. Considering the common occurrence of both FANCA polymorphism alleles, neither allele is expected to be a high penetrance predisposition allele. The current study evaluated whether duplication in the promoter region of the FANCA gene may increase breast cancer susceptibility. The results of the present study were consistent with previous epidemiological studies, which indicated the role of FANCA gene variations in increasing the risk of breast cancer (31). According to the results of the present study, FANCA gene mutations generally increase the risk of breast cancer and contribute to the development of familial breast cancer. Previous research has highlighted the role of various genes involved in DNA repair, other than $B R C A 1$ or $B R C A 2$, in increasing breast cancer susceptibility. For example, a study on the Finnish population reported that FANCM mutations caused a strong predisposition to breast cancer (31-35). Johnson et al (31) reported missense variants in the BRCA1, BRCA2, ATM, CHEK2 and ATM genes to be significantly associated with breast cancer risk among cases with bilateral disease $(\mathrm{P}=0.005)$, particularly for less common alleles $(\mathrm{P}=0.00004)$. However, despite the evidence to support the potential role of the FANCA family in increasing susceptibility to breast cancer and other types of cancer (15), the investigation of the role of these genes in cancer susceptibility in a monoallelic context has been limited. However, heterozygous FANCA deletions have been reported as potential low penetrance alleles for acute myeloid leukemia (16). Recently, Virts et al (36) in the US demonstrated the FANCT gene to be a rare cancer susceptibility gene. In a study on a Spanish population, Blanco et al (37) introduced RAD51 paralog C, a novel FA gene necessary for homologous recombination repair, as a rare susceptibility gene for hereditary breast and ovarian cancer. By contrast, Cleton-Jansen et al (38) reported the absence of mutations in 19 breast cancer patients with $16 \mathrm{q} 24.3$. 
Table V. Estimated risk of breast cancer for major risk factors in different genotypes.

\begin{tabular}{|c|c|c|c|c|c|}
\hline \multirow[b]{2}{*}{ Category } & \multirow[b]{2}{*}{ All } & \multicolumn{3}{|c|}{ Genotype } & \multirow[b]{2}{*}{ P-value } \\
\hline & & 01 & 11 & 00 & \\
\hline Age at menarche & & & & & 0.001 \\
\hline$\leq 12$ years $(\%)$ & 220 & $100(76.3)$ & $16(38.1) 26(61.9)$ & $104(80.6)$ & \\
\hline$>12$ years $(\%)$ & 82 & $31(23.7)$ & $26(61.9)$ & $25(19.4)$ & \\
\hline OR $(95 \% \mathrm{CI})$ & & $0.775(0.428-1.405)$ & $0.148(0.069-0.316)$ & 1 & \\
\hline Age at breast cancer onset & & & & & 0.335 \\
\hline$\leq 40$ years $(\%)$ & 118 & $57(44.2)$ & $14(34.1)$ & $47(36.4)$ & \\
\hline$>40$ years $(\%)$ & 181 & $72(55.8)$ & $27(65.9)$ & $82(63.6)$ & \\
\hline OR $(95 \%$ CI $)$ & & $1.381(0.838-2.276)$ & $0.905(0.432-1.893)$ & 1 & \\
\hline Age at menopause & & & & & 0.693 \\
\hline$\leq 50$ years $(\%)$ & 39 & $20(27.8)$ & $5(19.2)$ & $14(25.5)$ & \\
\hline$>50$ years $(\%)$ & 114 & $52(72.2)$ & $21(80.8)$ & $41(74.5)$ & \\
\hline OR $(95 \% \mathrm{CI})$ & & $1.126(0.508-2.497)$ & $0.697(0.221-2.199)$ & 1 & \\
\hline Metastasis status & & & & & 0.348 \\
\hline Yes $(\%)$ & 37 & $14(10.8)$ & $8(19)$ & 15 (11.6) & \\
\hline No $(\%)$ & 264 & $116(89.2)$ & $34(81)$ & $114(88.4)$ & \\
\hline OR $(95 \% \mathrm{CI})$ & & $0.917(0.423-1.987)$ & $1.788(0.699-4.576)$ & 1 & \\
\hline Cancer status & & & & & 0.001 \\
\hline Familial (\%) & 152 & $81(61.8)$ & $28(66.7)$ & $43(32.8)$ & \\
\hline Non-familial (\%) & 152 & $50(38.2)$ & $14(33.3)$ & $88(67.2)$ & \\
\hline OR $(95 \% \mathrm{CI})$ & & $3.315(1.996-5.506)$ & $4.093(1.957-8.561)$ & 1 & \\
\hline
\end{tabular}

OR and CI for 01 and 11 groups are presented relative to that of 00.00 , normal genotype; 01, duplication heterozygote; 11, duplication homozygote; OR, odds ratio; CI, confidence interval.

Genotyping of the promoter polymorphism indicated a significant difference in the allele or genotype distribution between patients with breast cancer and normal controls. The present study had $80 \%$ power to detect an OR $\geq 1.27$ for heterozygous carriers of the duplication and an $\mathrm{OR} \geq 1.511$ for homozygous carriers of the duplication in hereditary breast cancer. Furthermore, the frequency of the allele 1 was significantly higher in patients with a family history of breast cancer compared with the control group (45 and 21\%, respectively; $\mathrm{P}=0.001)$, indicating that allele 1 may increase the risk of breast cancer development. Nevertheless, larger studies are required to compare the frequency of FANCA gene sequence variants between breast cancer patients and healthy controls with different ethnicities. In conclusion, the current study was the first to report a promoter region variation in the FANCA gene among women with breast cancer in Iran. The results of the present study confirmed the allelic variants in the FANCA promoter region as a tumor suppressor gene. This gene affects cell activities, such as the basal rate of transcription or the regulation of transcription, which increase the risk of breast cancer. However, a more extensive evaluation of the role of other FA pathway genes in hereditary susceptibility to cancer is required. Further studies are required to clarify the full implication of FANCA gene variation in breast cancer susceptibility and predisposition to other types of cancer. Such genetic markers may be useful as an early breast cancer diagnosis tool in developing countries such as Iran.

\section{Acknowledgements}

The current study was supported by Tehran University of Medical Sciences and Health Services (grant no. 91-01-31-14816).

\section{References}

1. WHO: Global Burden of Disease. Geneva, Switzerland. 2004.

2. Jemal A, Siegel R, Ward E, Hao Y, Xu J, Murray T and Thun MJ: Cancer statistics, 2008. CA Cancer J Clin 58: 71-96, 2008.

3. Akbari ME, Abachizade K, Tabatabaei M, Ghanbari Motlagh A, Majd Jabari Z and Khayamzadeh M: Cancer in Iran. Darolfekr Publications, Ghom, 2008.

4. Kamangar F, Dores GM and Anderson WF: Patterns of cancer incidence, mortality, and prevalence across five continents: Defining priorities to reduce cancer disparities in different geographic regions of the world. J Clin Oncol 24: 2137-2150, 2006 .

5. Stratton MR and Rahman N: The emerging landscape of breast cancer susceptibility. Nat Genet 40: 17-22, 2008.

6. Joenje $\mathrm{H}$ and Patel KJ: The emerging genetic and molecular basis of Fanconi anaemia. Nat Rev Genet 2: 446-457, 2001.

7. Tischkowitz MD and Hodgson SV: Fanconi anaemia. J Med Genet 40: 1-10, 2003.

8. Pronk JC, Gibson RA, Savoia A, Wijker M, Morgan NV, Melchionda S, Ford D, Temtamy S, Ortega JJ, Jansen S, et al: Localisation of the Fanconi anaemia complementation group A gene to chromosome 16q24.3. Nat Genet 11: 338-340, 1995.

9. Han SS, Tompkins VS, Son DJ, Han S, Yun H, Kamberos NL, Dehoedt CL, Gu C, Holman C, Tricot G, et al: CDKN1A and FANCD2 are potential oncotargets in Burkitt lymphoma and multiple myeloma. Exp Hematol Oncol 4: 9, 2015. 
10. Medhurst AL, Huber PA, Waisfisz Q, de Winter JP and Mathew CG: Direct interactions of the five known Fanconi anaemia proteins suggest a common functional pathway. Hum Mol Genet 10: 423-429, 2001.

11. Hussain S, Witt E, Huber PA, Medhurst AL, Ashworth A and Mathew CG: Direct interaction of the Fanconi anaemia protein FANCG with BRCA2/FANCD1. Hum Mol Genet 12: 2503-2510, 2003.

12. Howlett NG, Taniguchi T, Olson S, Cox B, Waisfisz Q, De Die-Smulders C, Persky N, Grompe M, Joenje H, Pals G, et al: Biallelic inactivation of BRCA2 in Fanconi anemia. Science 297: 606-609, 2002.

13. Cleton-Jansen AM, Callen DF, Seshadri R, Goldup S, Mccallum B, Crawford J, Powell JA, Settasatian C, van Beerendonk H, Moerland EW, et al: Loss of heterozygosity mapping at chromosome arm 16q in 712 breast tumors reveals factors that influence delineation of candidate regions. Cancer Res 61: 1171-1177, 2001.

14. Haiman CA, Hsu C, de Bakker PI, Frasco M, Sheng X, Van Den Berg D, Casagrande JT, Kolonel LN, Le Marchand L, Hankinson SE, et al: Comprehensive association testing of common genetic variation in DNA repair pathway genes in relationship with breast cancer risk in multiple populations. Hum Mol Genet 17: 825-834, 2008.

15. Seal S, Barfoot R, Jayatilake H, Smith P, Renwick A, Bascombe L, McGuffog L, Evans DG, Eccles D, Easton DF, et al: Evaluation of Fanconi anemia genes in familial breast cancer predisposition. Cancer Res 63: 8596-8599, 2003.

16. Tischkowitz MD, Morgan NV, Grimwade D, Eddy C, Ball S, Vorechovsky I,Langabeer S,Stöger R,Hodgson SV and Mathew CG: Deletion and reduced expression of the Fanconi anemia FANCA gene in sporadic acute myeloid leukemia. Leukemia 18: 420-425, 2004.

17. Thompson E, Dragovic RL, Stephenson SA, Eccles DM, Campbell IG and Dobrovic A: A novel duplication polymorphism in the FANCA promoter and its association with breast and ovarian cancer. BMC Cancer 5: 43, 2005.

18. Abbasi S, Rasouli M, Nouri M and Kalbasi S: Association of estrogen receptor- $\alpha$ A908G (K303R) mutation with breast cancer risk. Int J Clin Exp Med 6: 39-49, 2013.

19. Beck A, Luedtke A, Liu K and Tintle N: A powerful method for including genotype uncertainty in tests of hardy-weinberg equilibrium. Pac Symp Biocomput 22: 368-379, 2016.

20. Colleu-Durel S, Guitton N, Nourgalieva K, Lévêque J, Danic B and Chenal C: Genomic instability and breast cancer. Oncol Rep 8: 1001-1005, 2001

21. Shen Y, Lee YH, Panneerselvam J, Zhang J, Loo LW and Fei P: Mutated Fanconi anemia pathway in non-Fanconi anemia cancers. Oncotarget 6: 20396-20403, 2015.

22. Bakker JL, Thirthagiri E, van Mil SE, Adank MA, Ikeda H, Verheul HM, Meijers-Heijboer H, de Winter JP, Sharan SK and Waisfisz Q: A novel splice site mutation in the noncoding region of BRCA2: Implications for Fanconi anemia and familial breast cancer diagnostics. Hum Mutat 35: 442-446, 2014.

23. Sawyer SL, Tian L, Kähkönen M, Schwartzentruber J, Kircher M; University of Washington Centre for Mendelian Genomics; FORGE Canada Consortium, Majewski J, Dyment DA, Innes AM, et al: Biallelic mutations in BRCA1 cause a new Fanconi anemia subtype. Cancer Discov 5: 135-142, 2015.

24. Venkitaraman AR: Connecting Fanconi's anaemia to breast cancer predisposition. Lancet 360: 1344-1345, 2002.

25. Van Der Heijden MS, Brody JR and Kern SE: Functional screen of the fanconi anemia pathway in cancer cells by Fancd2 immunoblot. Cancer Biol Ther 3: 534-537, 2004.
26. Turner N, Tutt A and Ashworth A: Hallmarks of 'BRCAness' in sporadic cancers. Nat Rev Cancer 4: 814-819, 2004.

27. Lewis AG, Flanagan J, Marsh A, Pupo GM, Mann G, Spurdle AB, Lindeman GJ, Visvader JE, Brown MA and Chenevix-Trench G; Kathleen Cuningham Foundation Consortium for Research into Familial Breast Cancer: Mutation analysis of FANCD2, BRIP1/BACH1, LMO4 and SFN in familial breast cancer. Breast Cancer Res 7 : R1005-R1016, 2005.

28. Solyom S, Winqvist R, Nikkilä J, Rapakko K, Hirvikoski P, Kokkonen $\mathrm{H}$ and Pylkäs K: Screening for large genomic rearrangements in the FANCA gene reveals extensive deletion in a Finnish breast cancer family. Cancer Lett 302: 113-118, 2011.

29. Zhu Y, Spitz MR, Lei L, Mills GB and Wu X: A single nucleotide polymorphism in the matrix metalloproteinase-1 promoter enhances lung cancer susceptibility. Cancer Res 61 7825-7829, 2001.

30. Bond GL, Hu W, Bond EE, Robins H, Lutzker SG, Arva NC, Bargonetti J, Bartel F, Taubert H, Wuerl P, et al: A single nucleotide polymorphism in the MDM2 promoter attenuates the p53 tumor suppressor pathway and accelerates tumor formation in humans. Cell 119: 591-602, 2004.

31. Johnson N, Fletcher O, Palles C, Rudd M, Webb E, Sellick G, dos Santos Silva I, McCormack V, Gibson L, Fraser A, et al: Counting potentially functional variants in BRCA1, BRCA2 and ATM predicts breast cancer susceptibility. Hum Mol Genet 16: 1051-1057, 2007.

32. Rodríguez-López R, Osorio A, Sánchez-Pulido L, De La Hoya M, Barroso A, Caldés T and Benítez J: No mutations in the XRCC2 gene in BRCA1/2-negative high-risk breast cancer families. Int J Cancer 103: 136-137, 2003.

33. Smith TR, Miller MS, Lohman K, Lange EM, Case LD, Mohrenweiser HW and Hu JJ: Polymorphisms of XRCC1 and XRCC3 genes and susceptibility to breast cancer. Cancer Lett 190: 183-190, 2003.

34. Kiiski JI, Pelttari LM, Khan S, Freysteinsdottir ES, Reynisdottir I, Hart SN, Shimelis H, Vilske S, Kallioniemi A, Schleutker J, et al: Exome sequencing identifies FANCM as a susceptibility gene for triple-negative breast cancer. Proc Natl Acad Sci USA 111: 15172-15177, 2014.

35. Fearnhead NS, Wilding JL, Winney B, Tonks S, Bartlett S, Bicknell DC, Tomlinson IP, Mortensen NJ and Bodmer WF: Multiple rare variants in different genes account for multifactorial inherited susceptibility to colorectal adenomas. Proc Natl Acad Sci USA 101: 15992-15997, 2004.

36. Virts EL, Jankowska A, Mackay C, Glaas MF, Wiek C, Kelich SL, Lottmann N, Kennedy FM, Marchal C, Lehnert E, et al: AluY-mediated germline deletion, duplication and somatic stem cell reversion in UBE2T defines a new subtype of Fanconi anemia. Hum Mol Genet 24: 5093-5108, 2015.

37. Blanco A, Gutiérrez-Enríquez S, Santamariña $M$, Montalban G, Bonache S, Balmaña J, Carracedo A, Diez O and Vega A: RAD51C germline mutations found in Spanish site-specific breast cancer and breast-ovarian cancer families. Breast Cancer Res Treat 147: 133-143, 2014.

38. Cleton-Jansen AM, Moerland EW, Pronk JC, van Berkel CG, Apostolou S, Crawford J, Savoia A, Auerbach AD, Mathew CG, Callen DF and Cornelisse CJ: Mutation analysis of the Fanconi anaemia A gene in breast tumours with loss of heterozygosity at 16q24.3. Br J Cancer 79: 1049-1052, 1999. 